\title{
Synaptic Connections of Calretinin-Immunoreactive Neurons in the Human Neocortex
}

\author{
María R. del Río and Javier DeFelipe \\ Instituto Cajal (Consejo Superior de Investigaciones Científicas), Madrid, Spain
}

Previous immunocytochemical studies in the cerebral cortex of various species have shown that the calcium-binding protein calretinin (CR) labels specific subpopulations of nonspiny nonpyramidal cells (interneurons). The present study attempts to characterize morphologically and chemically the microcircuitry of CR-immunoreactive (CR-ir) neurons in the human temporal neocortex. Postembedding immunocytochemistry for CR and GABA and combination immunocytochemistry for CR and nonphosphorylated neurofilament protein (NPNFP) or for CR and the calcium-binding proteins parvalbumin ( $P V)$ and calbindin (CB) showed CR multiterminal endings frequently innervating the distal apical dendrite or the cell body and proximal dendrites of NPNFP-ir or CB-ir pyramidal cells, respectively. Cell bodies of interneurons immunoreactive for $\mathrm{CB}$ or $\mathrm{PV}$ were innervated only occasionally by $\mathrm{CR}$ multiterminal endings, whereas certain GABA neurons were surrounded by them. Furthermore, CR-ir axon terminals formed either symmetrical (the majority) or asymmetrical synapses with a variety of postsynaptic elements. These results indicate that different subpopulations of CR interneurons exist that are specialized for selective innervation of somatic or dendritic regions of certain pyramidal and nonpyramidal neurons.

Key words: cortical circuitry; pyramidal cells; nonpyramidal cells; calcium-binding proteins; GABA; neurofilament protein; synapses
Neurons with local axons (interneurons) in the neocortex can be subdivided into two major groups: spiny and smooth nonpyramidal cells. Spiny nonpyramidal cells constitute a relatively small group of neurons located in the middle layers and are thought to be excitatory. Smooth nonpyramidal cells represent the largest group of interneurons and are thought to be inhibitory GABAergic cells and the main components of inhibitory neocortical circuits, which control the activity of projecting cells (pyramidal cells) (Houser et al., 1984; Hendry, 1987; Peters, 1987; Somogyi, 1989; White, 1989; Lund, 1990; Jones, 1993).

Immunocytochemical studies using antibodies against a variety of chemical compounds have revealed that certain subpopulations of smooth nonpyramidal cells display particular neurochemical characteristics (DeFelipe, 1993). Immunocytochemistry for the calciumbinding proteins parvalbumin (PV), calbindin D-28k (CB), and calretinin $(\mathrm{CR})$ has been especially useful for examining the synaptic connections or chemical characteristics of certain types of neurons (DeFelipe et al., 1989; Hendry et al., 1989; Lewis and Lund, 1990; Williams et al., 1992; Kawaguchi and Kubota, 1993; del Río and DeFelipe, 1994, 1995, 1997; Kawaguchi, 1995). Recent colocalization experiments have shown that in the human neocortex a small, but significant, population of CR-immunoreactive (CR-ir) neurons is non-GABAergic (del Río and DeFelipe, 1996a). Although the function of CR is still unknown (Andressen et al., 1993), this finding is of interest because this protein is localized in smooth nonpyramidal cells (Jacobowitz and Winsky, 1991; Glezer et al., 1992; Résibois and Rogers, 1992; Hof et al., 1993; Condé et al., 1994; Fonseca and Soriano, 1995; del Río and DeFelipe, 1996a). These colocalization

\footnotetext{
Received Jan. 17, 1997; revised April 16, 1997; accepted April 22, 1997.

This work was supported by Fondo de Investigaciones Sanitarias de la Seguridad Social Grant 96/2134. We thank A. Ortiz, J. R. Rodríguez, and J. A. Maldonado for technical assistance.

Correspondence should be addressed to Dr. J. DeFelipe, Instituto Cajal (Consejo Superior de Investigaciones Científicas), Avenida Dr. Arce 37, 28002 Madrid, Spain. Copyright (C) 1997 Society for Neuroscience $0270-6474 / 97 / 175143-12 \$ 05.00 / 0$
}

experiments suggest that CR immunocytochemistry labels two subpopulations of smooth nonpyramidal cells, one that consists of GABAergic neurons (the largest subpopulation) and the other of non-GABAergic neurons. This is in line with the observation that some CR-ir neurons are bipolar cells (Condé et al., 1994; del Río and DeFelipe, 1996a), whereas in other studies certain bipolar cells have been found to make asymmetrical synapses (Peters and Kimerer, 1981; Fairén et al., 1984; Peters and Harriman, 1988). Because GABA neurons establish exclusively symmetrical synapses (Ribak, 1978; Houser et al., 1984), the latter bipolar cells must be nonGABAergic. However, there are no studies on synaptic connections of CR-ir neurons in the human neocortex. The aim of the present work was to characterize morphologically and chemically the microcircuitry of CR-ir neurons in the human temporal neocortex by using electron microscopy and combination immunocytochemistry for CR and nonphosphorylated neurofilament protein (NPNFP), for CR and PV, or for CR and CB. Furthermore, postembedding immunocytochemistry for $\mathrm{CR}$ and GABA also was performed. Immunocytochemistry for NPNFP was used because of the excellent staining of the dendritic tree of subpopulations of pyramidal cells (Campbell and Morrison, 1989), which permitted the study of possible synaptic relationships of CR-ir axons with these pyramidal cells.

Preliminary results of this investigation have been published previously (del Río and DeFelipe, 1996b).

\section{MATERIALS AND METHODS}

Human cerebral cortical tissue considered to be normal (see Results) was examined from the anterolateral superior, middle, and inferior temporal gyri (Brodmann's area 38, 21, and 20, respectively). This tissue was removed inevitably during surgical treatment of eight patients (range 19-44 years old, mean 32.25 years old) with pharmaco-resistant temporal lobe epilepsy. For all patients, informed consent was obtained before surgery. Some of this material has been used in a previous study (Marco et al., 1996). All tissue samples were immersed immediately in cold $4 \%$ paraformaldehyde in $0.1 \mathrm{M}$ phosphate buffer (PB), $\mathrm{pH} 7.4$, for $2-3 \mathrm{hr}$ and then cut into small blocks and post-fixed in the same fixative, except for 
some blocks that were fixed in a mixture of $2 \%$ paraformaldehyde and $0.2 \%$ glutaraldehyde for $24 \mathrm{hr}$ at $4^{\circ} \mathrm{C}$. The blocks were cut at $100 \mu \mathrm{m}$ on a Vibratome, and the sections were pretreated with a solution of ethanol and hydrogen peroxide in PB to remove endogenous peroxidase activity. Sections from tissue fixed in $4 \%$ paraformaldehyde were processed for preembedding light and electron microscope immunocytochemistry and double immunocytochemical staining, while those sections from tissue fixed in $2 \%$ paraformaldehyde and $0.2 \%$ glutaraldehyde were processed for postembedding immunocytochemistry. Adjacent sections were stained with thionine.

Preembedding light and electron microscope immunocytochemistry. Sections were washed in $\mathrm{PB}$, preincubated in $3 \%$ normal goat serum in $\mathrm{PB}$ either with or without Triton X-100 $(0.05 \%)$ for $3 \mathrm{hr}$ at room temperature, and incubated for $24 \mathrm{hr}$ at $4^{\circ} \mathrm{C}$ in rabbit anti-CR (Swant, Bellinzona, Switzerland) diluted 1:2000 in PB containing 3\% normal goat serum either with or without Triton X-100 (0.05\%). Then the sections were washed in $\mathrm{PB}$ and processed by the avidin-biotin-peroxidase method with the Vectastain ABC immunoperoxidase kit (Vector Laboratories, Burlingame, CA). Afterward, the sections were washed in PB and reacted histochemically with $0.05 \% \quad 3,3^{\prime}$-diaminobenzidine tetrahydrochloride (DAB) and $0.01 \%$ hydrogen peroxide, washed again, and osmicated either in $0.02 \%$ osmium tetroxide for $1 \mathrm{~min}$ or in $1 \%$ osmium tetroxide in $\mathrm{PB}$ for $40 \mathrm{~min}$. Sections treated with Triton X-100 were osmicated in the first osmium solution, mounted onto glass slides, dehydrated, cleared with xylene, and coverslipped. These sections were used for light microcopy alone. The sections not treated with Triton X-100 were post-fixed in $1 \%$ glutaraldehyde in PB for $1 \mathrm{hr}$, osmicated in $1 \%$ osmium tetroxide dehydrated, and flat-embedded in Araldite resin. These plasticembedded sections were examined by using a correlative light and electron microscopic method described in detail elsewhere (DeFelipe and Fairén, 1993). Most of the ultrathin sections were stained with uranyl acetate and lead citrate, whereas the others were examined unstained in a Jeol-1200 EX electron microscope. Neuronal size was measured directly from light microscope slides by using an eyepiece reticle.

Double immunocytochemical staining. Two methods were used for double immunocytochemical staining. The sections processed with the first method were examined by conventional light microscopy, whereas those with the second method were analyzed by confocal laser icroscopy.

For conventional light microscopy, dual immunostaining for two substances was achieved by using sequential immunocytochemistry for the first substance and then for the second substance, first with DAB-nickel and then with DAB as substrates to visualize the bound immunoglobulinperoxidase complexes in black and brown, respectively (Hancock, 1982). Briefly, sections first were stained immunocytochemically for CR, as above, except that Triton X-100 (0.2\%) was added in the preincubation and first incubation steps and that a $0.05 \%$ solution of DAB containing $2.5 \%$ nickel ammonium sulfate and $0.01 \%$ hydrogen peroxide was used to visualize immunoreactive elements. Afterward, the sections were washed and reprocessed immunocytochemically as follows: for NPNFP, using the mouse monoclonal antibody SMI 32 (Sternberger Monoclonals, Baltimore, MD) diluted 1: 5000; for CB, using rabbit anti-CB (Swant) diluted 1:2000; or for PV, using mouse monoclonal anti-PV (Swant) diluted 1:2000. The immunocytochemical procedure was the same as that described for CR, using the appropriate species-specific Vectastain ABC immunoperoxidase kits (Vector Laboratories), but the sections were reacted histochemically with $0.05 \%$ DAB and $0.01 \%$ hydrogen peroxide. Finally, the sections were dehydrated, cleared with xylene, and coverslipped.

For confocal laser microscopy, sections were double-stained only for $\mathrm{CR}$ and $\mathrm{CB}$ by the following technique. The sections were incubated for $24 \mathrm{hr}$ at $4^{\circ} \mathrm{C}$ in a solution containing the same rabbit polyclonal anti-CR antibody and mouse monoclonal anti-CB antibody, as indicated above, diluted 1:2000. Then the sections were incubated for $1 \mathrm{hr}$ at room temperature in a solution containing biotinylated goat anti-rabbit IgG (Vector Laboratories) diluted 1:200. Thereafter, the sections were washed in $\mathrm{PB}$ and incubated for $1 \mathrm{hr}$ at room temperature in a mixture of Cy5-conjugated goat anti-mouse IgG and Cy2-conjugated streptoavidin (Amersham, Arlington Heights, IL) diluted 1:1000. Finally, the sections were mounted, coverslipped in a 1:3 solution of PB and glycerol, and examined in a Leica TCS 4D confocal laser scanning microscope equipped with an argon/krypton-mixed gas laser with excitation peaks at $489 \mathrm{~nm}$ (for Cy2-labeled profiles) and $649 \mathrm{~nm}$ (for Cy5-labeled profiles). The confocal microscope was associated with a Leitz DMIRB fluorescence microscope. Fluorescence of Cy2-labeled profiles and Cy5-labeled profiles was recorded through separate channels.

Postembedding immunocytochemistry. Vibratome sections from tissue fixed in $2 \%$ paraformaldehyde and $0.2 \%$ glutaraldehyde were post-fixed in $1 \%$ osmium tetroxide for $30 \mathrm{~min}$, dehydrated, and flat-embedded in Araldite resin. Serial 1- $\mu$ m-thick plastic (semithin) sections were cut with a Reichert ultramicrotome and processed by the postembedding immunocytochemical staining protocol for CR and GABA described in del Río and DeFelipe (1996a). The anti-CR was the same as above, and the anti-GABA was a rabbit polyclonal antiserum (Sigma, St. Louis, MO).

Control sections for immunocytochemistry were processed as above, but with the primary antibody replaced with normal serum and, additionally in the case of $\mathrm{CR}, \mathrm{CB}$, and PV immunocytochemistry, with primary antibody adsorbed with an excess of $\mathrm{CR}, \mathrm{CB}$, and PV proteins (Swant), as indicated by the manufacturer or, in the case of GABA immunocytochemistry, with primary antiserum adsorbed with an excess of GABA albumin conjugate. No significant staining was observed under these control conditions.

\section{RESULTS}

The human temporal neocortex used in the present study was considered to be normal, a conclusion based on intraoperative electrocorticography and routine histopathological examinations and other immunocytochemical studies done on the resected tissue (see Marco et al., 1996). Furthermore, the normal appearance of the cytoarchitecture and the patterns of immunostaining observed in the present study were very similar to those observed in tissue sections from normal temporal neocortex that had been removed from a 34-year-old nonepileptic patient to gain access to a tumor located near the hippocampus (del Río and DeFelipe, 1997). Thus, the general observations and conclusions on the connectivity of CR-ir neurons described below are likely to be found also in strictly normal human temporal cortex. Unless otherwise specified, the following description refers to observations made on material examined with conventional light microscopy.

\section{CR immunoreactivity}

CR-ir neurons comprised a population of nonpyramidal cells that were distributed from layers I to VI and in the subjacent white matter but that were most numerous in layers II and III. They had small somata (diameter $8-12 \mu \mathrm{m}$ ) and showed a variety of shapes (round, fusiform, bipolar, multipolar) (Fig. 1A). As described in our earlier study (del Río and DeFelipe, 1996a), the most typical morphology was the bipolar form (Feldman and Peters, 1978), which was distinguished by a round or fusiform soma, which furnished primary dendrites from the upper and lower poles, and by a long, narrow, and vertically orientated dendritic tree (Fig. $1 B)$. Three kinds of immunoreactive elements were found in the neuropil: terminal-like puncta and axonal and dendritic processes. Axonal processes were very thin and very finely beaded with varicosities of $0.5-1 \mu \mathrm{m}$ in diameter and were distributed nonuniformly. Dendritic processes were either thick and nonbeaded or were thin and coarsely beaded with round or ovoid varicosities; they were distributed rather uniformly (Fig. $1 B$ ). Terminal-like

Figure 1. CR immunostaining through the middle temporal gyrus (Brodmann's area 21). $A$, Low power photomicrograph from layers II-III showing examples of CR-ir neurons. Note that many immunoreactive neurons display a bipolar or bitufted morphology with vertically oriented processes. $B$, Higher magnification photomicrograph of $A$ showing a typical bipolar cell ( $b$; also indicated in $A$ ) with a long and nonbeaded ascending dendrite (open arrow). Two arrows indicate a coarsely beaded dendritic process. $C-E$, Double immunocytochemical staining for CR/NPNFP (Figure legend continues) 

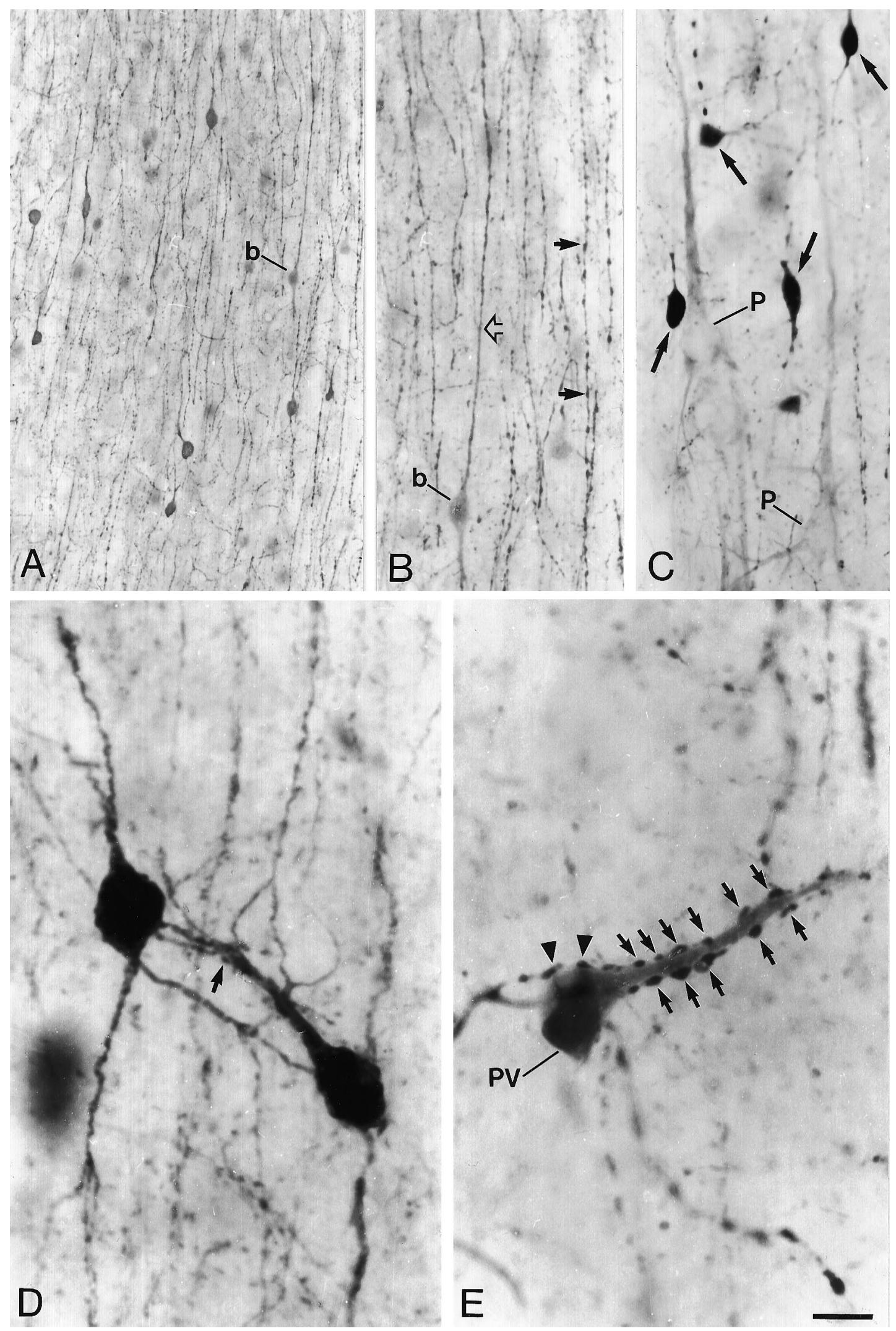

$(C)$ and for $\mathrm{CR} / \mathrm{PV}(D, E)$. CR-ir elements were labeled in black, using DAB-nickel as the substrate to visualize the bound immunoglobulin-peroxidase complexes, whereas NPNFP-ir and PV-ir elements were labeled in brown, using DAB as the substrate (see Fig. $2 A, B$ in color). $C$, Photomicrograph showing CR-ir nonpyramidal cells (arrow) and NPNFP-ir pyramidal cells $(p)$, which are not innervated by CR-ir terminals. $D$, Photomicrograph illustrating dendro-dendritic contacts (arrow) between two CR-ir nonpyramidal cells. E, High magnification photomicrograph showing dendro-somatic (arrowheads) and dendro-dendritic (arrows) contacts between a CR-ir neuron and a PV-ir neuron ( $P V$ ). A low magnification photomicrograph of these immunoreactive neurons is shown in Figure $2 B$ in color. Scale bars: $50 \mu \mathrm{m}$ for $A ; 24 \mu \mathrm{m}$ for $B, C ; 8 \mu \mathrm{m}$ for $D, E$. 
puncta also were found frequently around unstained neurons, mainly in layers II and III. However, few or no CR-ir axons were observed contacting other CR-ir neurons, but close appositions between dendrites and between dendrites and somata of pairs of CR-ir neurons were found relatively often (Fig. 1D).

\section{Double immunocytochemical staining General}

The double immunocytochemical staining method used for conventional light microscopy allowed the visualization of two sets of immunoreactive elements in the same section by using DABnickel and $\mathrm{DAB}$ as substrates for the differential staining of immunoreactive elements. With DAB-nickel the immunoreactive neurons and processes were stained an intense black, whereas with $\mathrm{DAB}$ the immunoreactive elements were stained brown (Figs. $1 C, 2 A, B)$. After double staining there was a decrease in intensity of immunostaining, particularly of the immunoreactive elements visualized with DAB. Because the primary objective of dual immunostaining was to study the relationship between CR-ir axons and neurons immunoreactive for NPNFP, CB, and PV, in all combinations $\mathrm{CR}$ immunocytochemistry was used first (with DAB-nickel), and afterward immunocytochemistry for the other substances (with DAB) was used.

The patterns of immunostaining for CR, NPNFP, CB, and PV in the human temporal neocortex have been described previously in other studies (Campbell and Morrison, 1989; Ferrer et al., 1991, 1992; Hof et al., 1991, 1993; Hayes and Lewis, 1992; del Río and DeFelipe, 1994; Fonseca and Soriano, 1995). Therefore, only a brief description of immunoreactive neurons will follow.

Immunocytochemistry for NPNFP, CB, and PV labeled the cell body, axon (except for NPNFP, which labeled only the axon initial segment, but not preterminal or terminal axons), and proximal dendrites of a variety of neurons. NPNFP immunocytochemistry labeled numerous pyramidal cells (Figs. $1 C, 2 A$ ) located in layers II through VI, but layers III, V, and VI contained the greatest number of stained cells. The size of the cell body and intensity of staining were variable, the largest and strongest-labeled pyramidal cells being located in the deep half of layer III and the superficial part of layer V. The apical dendrites of many labeled pyramidal cells could be followed for several tens or even hundreds of microns (Figs. $1 C, 2 A, 3 A-D$ ). CB-ir neurons consisted of both pyramidal (Fig. $3 E$ ) and nonpyramidal cells (Fig. $3 F$ ). In general, pyramidal cells were lightly labeled and located mainly in layer III, whereas nonpyramidal cells were darkly stained and found in all layers, although the majority was found in layers II and III. The shape and size of nonpyramidal cells were variable, but the most common morphology was multipolar with a rounded soma of $\sim 10$ $\mu \mathrm{m}$ in diameter. PV immunocytochemistry labeled nonpyramidal cells located in layers II through VI. Most immunoreactive cells were darkly stained and showed a variety of forms, the multipolar morphology showing an ovoid soma of $10-15 \mu \mathrm{m}$ in diameter being one of the most common. Some multipolar cells were similar to large basket cells (Marin-Padilla, 1969; Jones, 1975); that is, they had a large cell body (20 $\mu \mathrm{m}$ or more in diameter) and long dendrites.

\section{Combination of CR and NPNFP immunocytochemistry}

The relationship between CR-ir axons and NPNFP-ir pyramidal cells appears to be highly selective, because many NPNFP-ir pyramidal cells in layers III and $\mathrm{V}$ were seen innervated by $\mathrm{CR}$-ir terminal-like puncta (Figs. $2 A, 3 A-D$ ), whereas many others showed a lack of these contacts (Fig. $1 C$, Table 1). Furthermore,
Table 1. Percentage of neurons immunoreactive for nonphosphorylated neurofilament protein (NPNFP), calbindin (CB), and parvalbumin (PV) found to be innervated by calretinin-immunoreactive multiterminals in layer III of the middle temporal gyrus

\begin{tabular}{lll} 
& $\begin{array}{l}\text { Pyramidal } \\
\text { cells }(\%)\end{array}$ & $\begin{array}{l}\text { Nonpyramidal } \\
\text { cells }(\%)\end{array}$ \\
\hline NPNFP & 20.7 & 0 \\
CB & 42.1 & 0 \\
PV & 0 & 3.4
\end{tabular}

Each value is a calculation made from a total of 20 rectangles $65 \times 650 \mu \mathrm{m}$ (parallel to the cortical surface) for each combination by using an eyepiece reticle. The total number of immunoreactive cells in each count is for NPNFP, 53 pyramidal and 0 nonpyramidal cells; for CB, 19 pyramidal and 28 nonpyramidal cells; and for PV, 0 pyramidal and 89 nonpyramidal cells.

multiterminal endings frequently were observed innervating the distal apical dendrites of NPNFP-ir pyramidal cells, whereas the cell body and proximal dendrites of these pyramidal cells were innervated by few or no CR-ir terminal-like puncta (Figs. $2 A, 3 A$ ). Therefore, CR-ir axons innervate preferentially the distal apical dendrites of certain NPNFP-ir pyramidal cells. In addition, some long, vertically oriented CR-ir dendritic processes also were found in close apposition to apical dendrites of NPNFP-ir pyramidal cells (Fig. 3D).

\section{Combination of $C R$ and $C B$ immunocytochemistry}

Numerous CB-ir pyramidal cells also were seen innervated by CR-ir axon terminals (Table 1). However, the relationship between CR-ir axons and CB-ir pyramidal cells was inverse with respect to the relationship between CR-ir axons and NPNFP-ir pyramidal cells; that is, CR-multiterminal endings frequently were observed around the cell body and proximal dendrites of CB-ir pyramidal cells (Fig. 3E), whereas only occasional CR-ir terminals were observed contacting the apical dendrites of these pyramidal cells. No dendro-dendritic close appositions were observed.

Because in sections from the human temporal neocortex stained for CB there were found pyramidal cells surrounded by CB-ir terminals (del Río and DeFelipe, 1996a), double-labeling immunofluorescence experiments were performed to study whether CR-ir and CB-ir pericellular axons converged or not on the same pyramidal cell somata. In this material (Fig. $2 C-E$ ) we found that numerous pyramidal cells were innervated by both CR-ir (Fig. 2C) and CB-ir (Fig. 2D) terminals, but double-labeled pericellular axon terminals were scarce (Fig. $2 E$ ), which indicated that most of these axons had different origins.

Cell bodies and proximal dendrites of CB-ir nonpyramidal cells were not observed innervated by dense CR-ir multiterminal endings (Fig. $3 F$, Table 1): only one or two CR-ir axon terminals occasionally were observed innervating CB-ir nonpyramidal cells. No dendro-dendritic close appositions were seen.

\section{Combination of $C R$ and PV immunocytochemistry}

The relationship between CR-ir axons and PV-ir nonpyramidal cells was similar to that found between CR-ir axons and CB-ir nonpyramidal cells. That is, few pericellular CR-ir terminals were seen around PV-ir nonpyramidal cells (Table 1). However, long dendritic segments of CR-ir neurons with bitufted or multipolar morphology frequently were observed in close apposition to dendrites of PV-ir neurons (Figs. $1 E, 2 B$ ). The dendrites in contact did not have a preferred orientation, and they often also contacted the soma (Fig. 2B). 


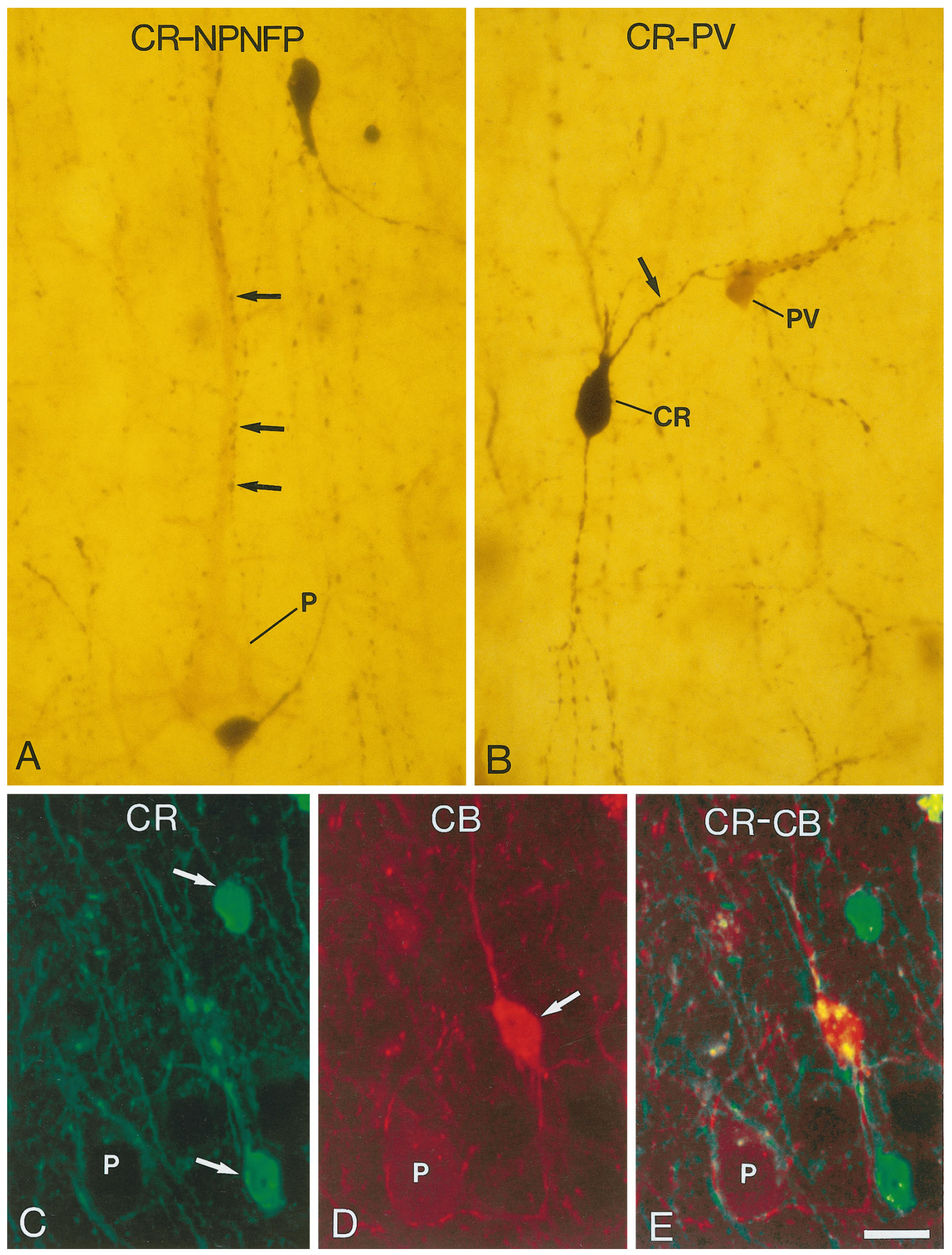

Figure 2. $A, B$, Double immunocytochemical staining for CR/NPNFP $(A)$ and for CR/PV $(B)$. $A$, Photomicrograph illustrating CR-ir multiterminal endings (arrows) innervating the apical dendrite of a NPNFP-ir pyramidal neuron $(p)$. $B$, Photomicrograph showing an example of close apposition between a dendritic process (arrow) from a CR-ir neuron $(C R)$ and the soma and dendrite of a PV-ir neuron $(P V)$. These contacts are shown at a higher magnification in Figure 1E. $C, D$, A pair of pseudocolored confocal images showing a pyramidal cell soma $(p)$ innervated by axon terminals labeled for Cy2-labeled CR $(C)$ and Cy5-labeled CB $(D)$. Labeled neurons are indicated with arrows. E, Pseudocolored confocal image obtained after combining the images recorded through the Cy2 and Cy5 channels. Double-labeled neurons and processes are seen in yellow. Note that none of the immunoreactive neurons is double-labeled and that the Cy2-labeled CR and Cy5-labeled CB pericellular terminals are not double-labeled, which indicates that these axons have different origins. Scale bars: $13.5 \mu \mathrm{m}$ for $A, B ; 22.5 \mu \mathrm{m}$ for $C-E$. 

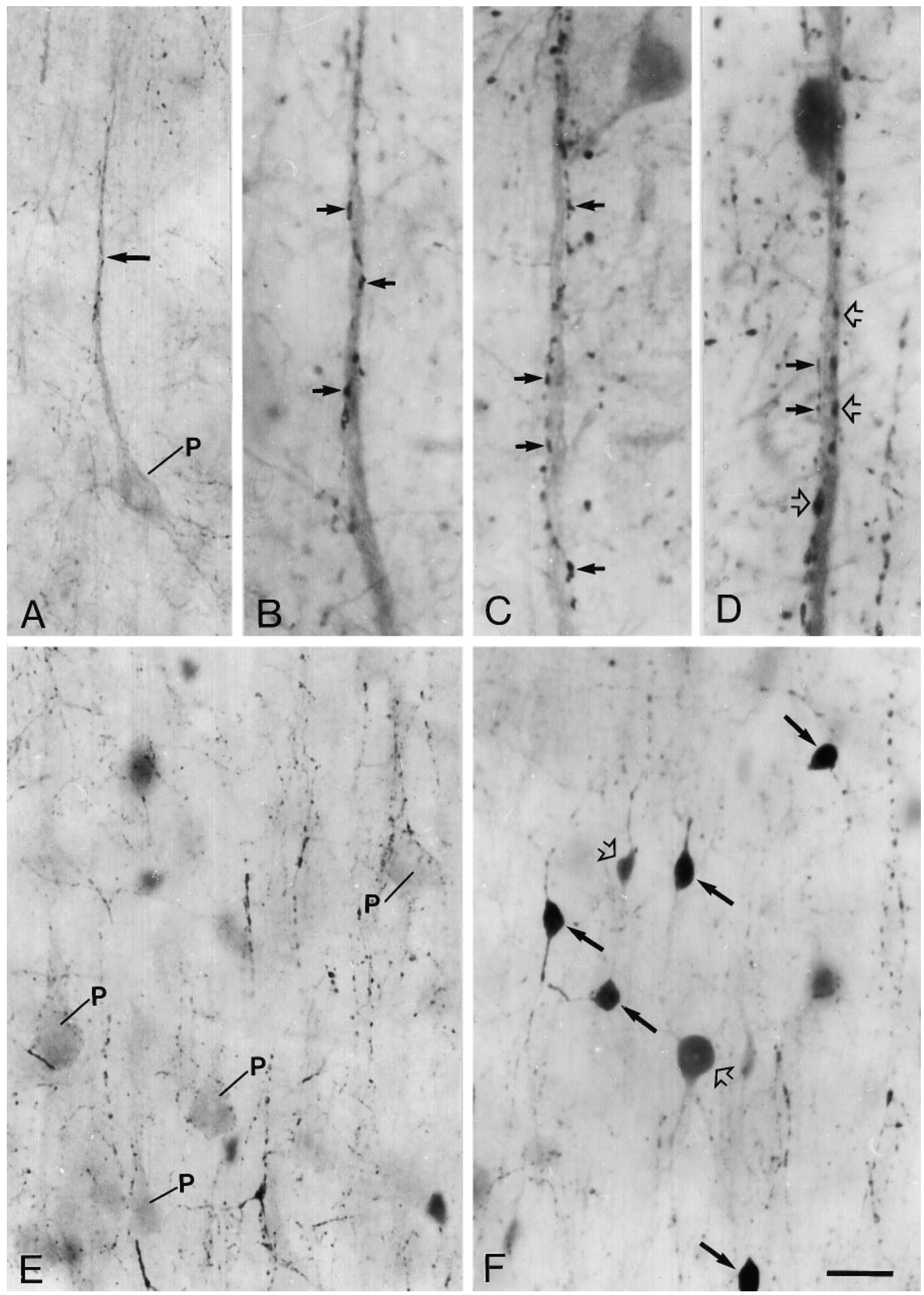

Figure 3. Double immunocytochemical staining for CR/NPNFP $(A-D)$ and for CR/CB $(E, F)$. $A$, Photomicrograph showing an example of NPNFP-ir pyramidal neuron $(p)$ located in layer III, the apical dendrite of which is innervated by CR-ir multiterminal endings (arrow). B, Higher magnification photomicrograph of $A$ illustrating the portion of the apical dendrite innervated by CR-ir terminals (arrows). $C, D$, Photomicrographs of two apical dendrites in layer III originating from NPNFP-ir pyramidal neurons located in layer V, which are innervated by CR-ir processes. One of the apical dendrites $(C)$ shows only axo-dendritic contacts (arrows), whereas the other $(D)$ shows both axo-dendritic (arrows) and dendro-dendritic (open arrows) contacts. $E$, Photomicrograph showing the cell body and proximal apical dendrites of CB-ir pyramidal cells $(p)$ innervated by CR-ir multiterminal endings. $F$, Photomicrograph showing CR-ir (arrows) and CB-ir (open arrows) nonpyramidal cells, the cell bodies and proximal dendrites of which are free of immunoreactive terminals. Scale bars: $50 \mu \mathrm{m}$ for $A ; 10.5 \mu \mathrm{m}$ for $B-D ; 36.5 \mu \mathrm{m}$ for $E, F$. 

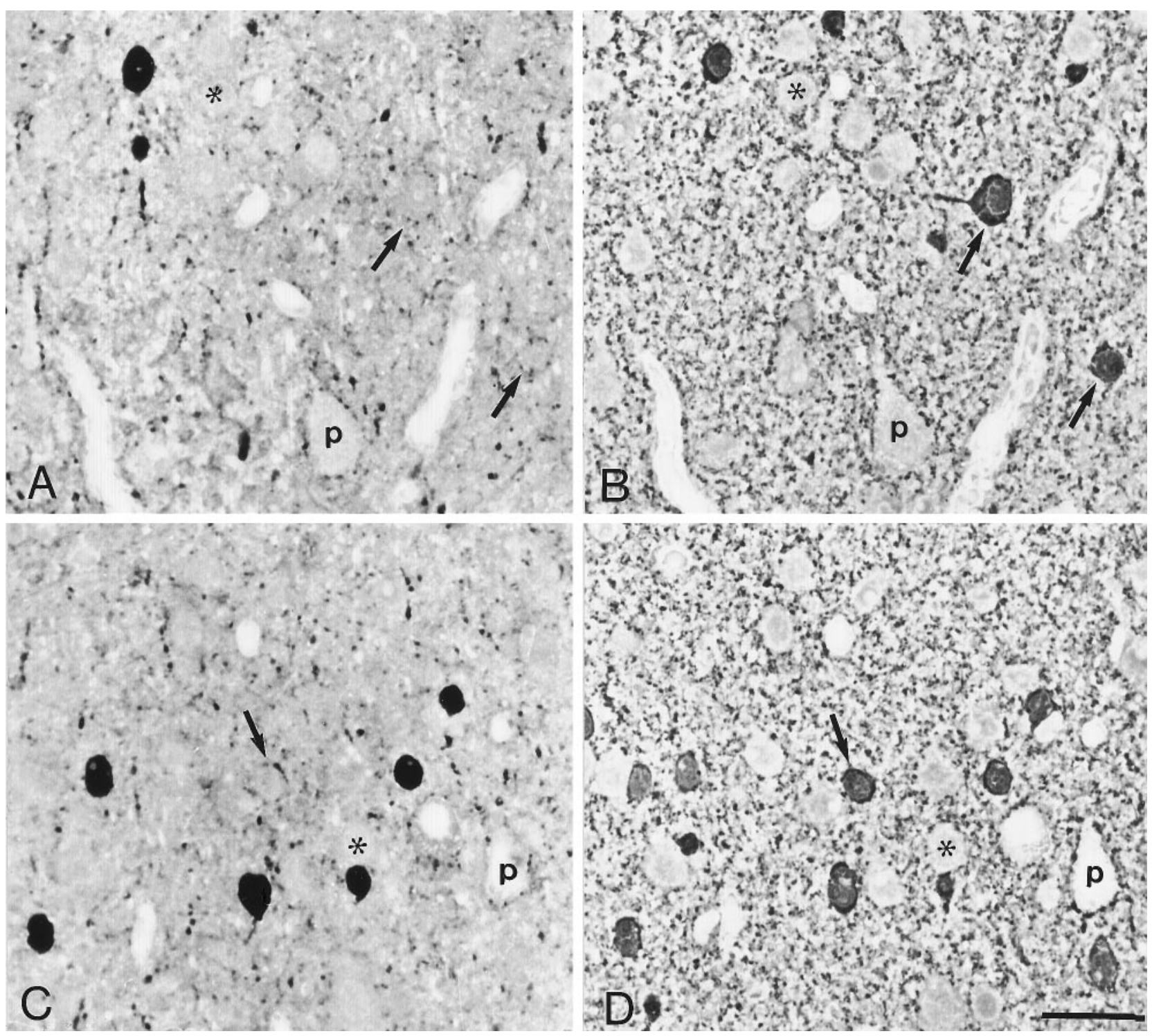

Figure 4. Pairs of photomicrographs $(A, B ; C, D)$, each showing two serial semithin sections immunocytochemically stained either for CR $(A, C)$ or for GABA $(B, D)$. Arrows indicate neurons that are GABA-ir, but not CR-ir, and that are innervated by CR-ir terminals. Some nonimmunoreactive pyramidal neurons $(p)$ innervated by both CR-ir and GABA-ir terminals are observed. Asterisks indicate some nonimmunoreactive neurons innervated only by GABA-ir terminals. Scale bar, $30 \mu \mathrm{m}$ for $A-D$.

\section{Postembedding immunocytochemistry for $C R$ and GABA}

To study the relationship between CR-ir neurons and GABA-ir and non-GABA-ir neurons, we used postembedding immunocytochemistry in 2- $\mu$ m-thick semithin sections (Fig. 4), because in our material the quality of immunostaining (labeling of cells and puncta) was superior to that achieved with preembedding GABA immunocytochemistry. However, the dendrites of GABA-ir neurons were not stained; therefore, the examination of the relationship between CR-ir neurons and GABA-ir and non-GABA-ir neurons was limited to the innervation of their somata. In serial semithin sections it was observed that neurons that were GABA-ir, but not CR-ir, commonly were innervated by CR-ir terminals, whereas very few CR-ir terminals were seen around the soma of neurons that were immunoreactive for both CR and GABA (cells labeled with arrows in Fig. 4). Furthermore, we distinguished two types of neurons that were not immunoreactive for either CR or GABA: type 1 cells (the majority) were characterized by their somata being surrounded by numerous
GABA-ir terminals, but not by CR-ir terminals (cells labeled with asterisks in Fig. 4), and type 2 cells, the somata of which were surrounded by both GABA-ir and CR-ir terminals (cells labeled with $p$ in Fig. 4). Many cells that were not immunoreactive for GABA and $\mathrm{CR}$ were identified as pyramidal cells because of their triangular or conic shape from which arose an apical dendrite.

\section{Electron microscope observations}

Six immunoreactive cell bodies of small size $(\sim 10 \mu \mathrm{m}$ in diameter) from the middle temporal gyrus were examined at the electron microscope level. They displayed similar ultrastructural features and were characterized by a large nucleus containing clumped chromatin and by the small volume occupied by a cytoplasm poor in organelles (Fig. 5A). Furthermore, there were few axosomatic synapses. Typically, it was necessary to search three or more serial ultrathin sections to find a terminal forming an axosomatic synapse. Immunoreactive dendrites presented typical or- 


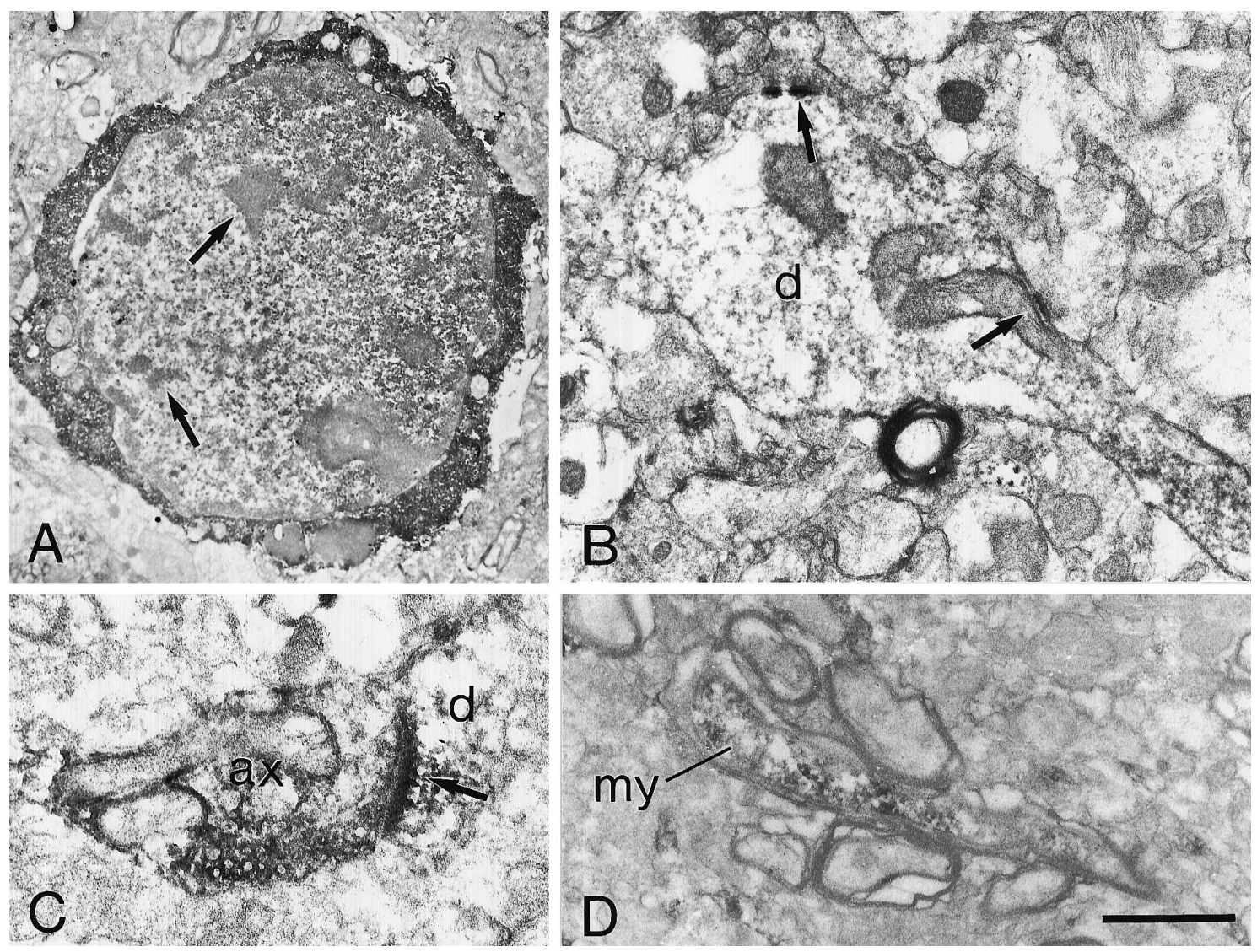

Figure 5. Electron micrographs of CR-ir elements. $A$, Example of a small CR-ir soma, which displays a large nucleus containing clumped chromatin (arrows). Note the small volume occupied by the cytoplasm. B. Example of an immunoreactive varicose dendrite (d) that receives two synapses (arrows). $C$, Immunoreactive axon terminal ( $a x)$ forming an asymmetrical synaptic contact (arrow) with an immunoreactive dendritic profile $(d)$. $D$, Example of an immunoreactive myelinated axon (my). Electron micrographs $B$ and $C$ were taken from ultrathin sections stained with uranyl acetate and lead citrate, whereas $A$ and $D$ were taken from unstained sections. Scale bars: $2 \mu \mathrm{m}$ for $A ; 0.55 \mu \mathrm{m}$ for $B ; 0.4 \mu \mathrm{m}$ for $C ; 0.8 \mu \mathrm{m}$ for $D$.

ganelles and showed no particular characteristics that distinguished them from other dendrites (Fig. 5B). However, they received numerous synapses, as compared to the cell body; in single sections of dendritic segments from a few microns long, one or more axodendritic synapses were found (arrows in Fig. 5B).

The distribution of CR-ir puncta was studied first in semithin sections. In these sections numerous CR-ir puncta were seen around unstained neuronal somata and in the neuropil intervening among the cell bodies and blood vessels. Selected semithin sections from layers II and III were resectioned for electron microscopy. At the electron microscope level most CR-ir puncta were identified as axon terminals, but dendrites (Fig. $5 C$ ) and myelinated (Fig. 5D) and unmyelinated axons were also among the CR-ir elements. A majority of perisomatic CR-ir axon terminals were seen around unstained pyramidal cells (Fig. $6 A, C$ ), and they formed symmetrical synapses (Fig. 6B). However, some CR-ir axon terminals were observed around nonpyramidal cell somata, and they formed either asymmetrical or symmetrical synapses, but we did not intend a quantitative analysis to study further the somatic innervation of pyramidal and nonpyramidal cells.

In the neuropil, CR-ir axon terminals formed either symmetrical (Fig. $7 A, B$ ) or asymmetrical (Fig. $7 C-F$ ) synapses with dendritic profiles. The vast majority of these dendritic profiles was nonimmunoreactive for $\mathrm{CR}$, and only occasionally a CR-ir axon terminal forming a synapse with a CR-ir dendritic profile
Table 2. CR-immunoreactive axon terminals forming asymmetrical and symmetrical synapses in layers II-III of the middle temporal gyrus

\begin{tabular}{llc} 
& $\begin{array}{l}\text { Asymmetrical } \\
\text { synapses }(\%)\end{array}$ & $\begin{array}{c}\text { Symmetrical } \\
\text { synapses }(\%)\end{array}$ \\
\hline Spines & $23(51.11)$ & $3(3.06)$ \\
$\begin{array}{l}\text { Dendritic shafts } \\
\text { Unidentified }\end{array}$ & $12(26.66)$ & $88(89.79)$ \\
$\quad$ elements & \\
Total & $10(22.23)$ & $7(7.15)$ \\
\hline
\end{tabular}

Distribution of 143 synapses made by CR-immunoreactive axon terminals (random sample) forming clearly identifiable morphological types of synapses. The percentages of the total number of identified synapses are in parentheses.

${ }^{a}$ Unidentified elements are small caliber $(<1 \mu \mathrm{m})$ postsynaptic elements that could not be identified as spines or dendritic shafts.

was found (Fig. $5 C$ ). In the latter cases the postsynaptic densities were more prominent than those found on unstained postsynaptic elements. To study quantitatively the synaptic distribution of CR-ir axon terminals in the neuropil, we analyzed a random sample of 143 synapses made by CR-ir axon terminals forming clearly identifiable morphological types of synapses (asymmetrical or symmetrical) with unstained postsynaptic elements (Table 2). Approximately $31 \%$ were of the asymmetrical type and $69 \%$ of the symmetrical type. The vast majority of postsynaptic elements $(88 \%)$ could be identi- 

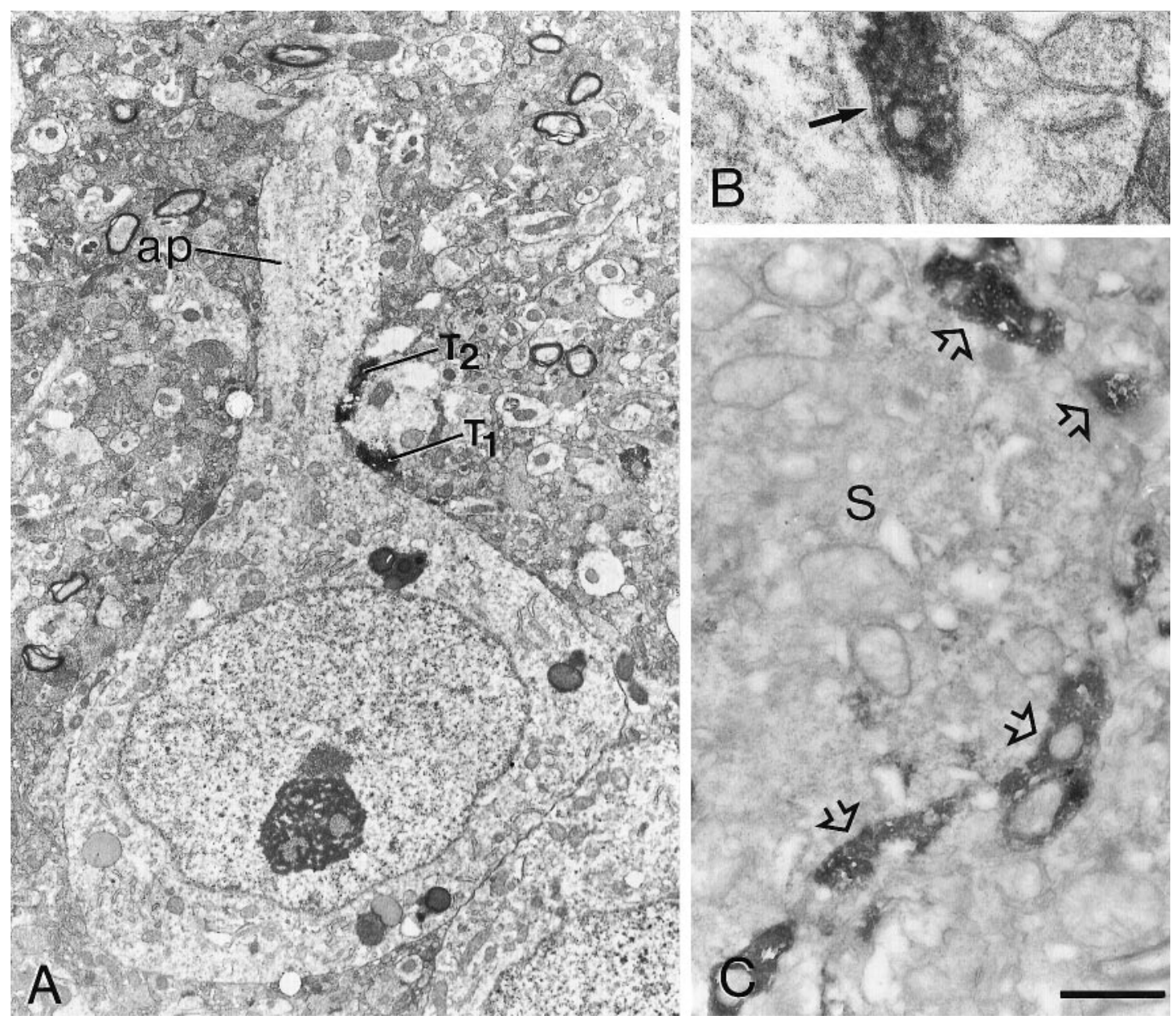

Figure 6. Electron micrograph showing perisomatic CR-ir terminals around somata of pyramidal cells. $A$, Two CR-ir terminals (T1 and $T 2)$ are seen in contact with the soma (T1) and at the commencement of the apical dendrite (T2). ap, Apical dendrite. $B$, High magnification of terminal $T 1$ in a serial section forming a symmetrical synapse (arrow) with the pyramidal cell soma. $C$, A soma $(S)$ surrounded by numerous CR-ir terminals (open arrows). Electron micrographs $A$ and $B$ were taken from ultrathin sections stained with uranyl acetate and lead citrate, whereas $C$ was taken from an unstained section. Scale bars: $2 \mu \mathrm{m}$ for $A ; 0.5 \mu \mathrm{m}$ for $B ; 0.23 \mu \mathrm{m}$ for $C$.

fied as large proximal dendrites or thinner (presumably more distal) dendrites and dendritic spines (Fig. 7). Unidentified postsynaptic elements displayed a small caliber $(<1 \mu \mathrm{m})$, and they could not be identified as spines or dendritic shafts. Approximately 50 and $26 \%$ of CR-ir asymmetrical synapses were found on spines and dendritic shafts, respectively, whereas for CR-ir symmetrical synapses these proportions were 3 and $89 \%$. Thus, in the neuropil, CR-ir axon terminals forming asymmetrical synapses preferentially innervated spines, whereas those forming symmetrical synapses preferentially contacted dendritic shafts.

\section{DISCUSSION}

The present work makes these main observations: (1) CR-ir multiterminal endings frequently innervated the distal apical dendrites of NPNFP-ir pyramidal cells and the cell body and proximal dendrites of CB-ir pyramidal cells. Nonpyramidal cell bodies immunoreactive for $\mathrm{CR}, \mathrm{CB}$, or PV were innervated only occasionally by $\mathrm{CR}$-ir axons, whereas certain GABA-ir neurons, which were not CR-ir, were surrounded by CR-ir multiterminal endings; (2) some CR-ir dendrites were found in close apposition to the apical dendrites of NPNFP-ir pyramidal cells or dendrites and somata of other CR-ir or PV-ir nonpyramidal neurons, but no such appositions were observed with CB-ir neurons; and (3) CR-ir axon terminals formed either asymmetrical or symmetrical synapses with various postsynaptic elements.

\section{Relationship between CR-ir multiterminal endings and pyramidal cells}

Immunocytochemistry for $\mathrm{CR}$ revealed numerous unstained pyramidal cell bodies surrounded by CR-ir multiterminal endings. Combination immunocytochemistry for CR/NPNFP or for $\mathrm{CR} / \mathrm{CB}$ showed that many pyramidal cells immunoreactive for NPNFP or CB were innervated by CR-ir multiterminal endings. However, the number of NPNFP-ir or CB-ir pyramidal cells was relatively small, as compared with the high number of pyramidal cells observed that were innervated by CR-ir axons not immunoreactive for either NPNFP or CB. Thus, NPNFP-ir and CB-ir pyramidal cells represented a subpopulation of the pyramidal cells innervated by CR-ir axons. Preferential innervation of the distal apical dendrites in the case of NPNFP-ir pyramidal cells, and of the cell body and proximal dendrites in the case of CB-ir pyramidal cells, indicates that the origins of the two kinds of CR-ir axons innervating these cells were from different types of neurons. 

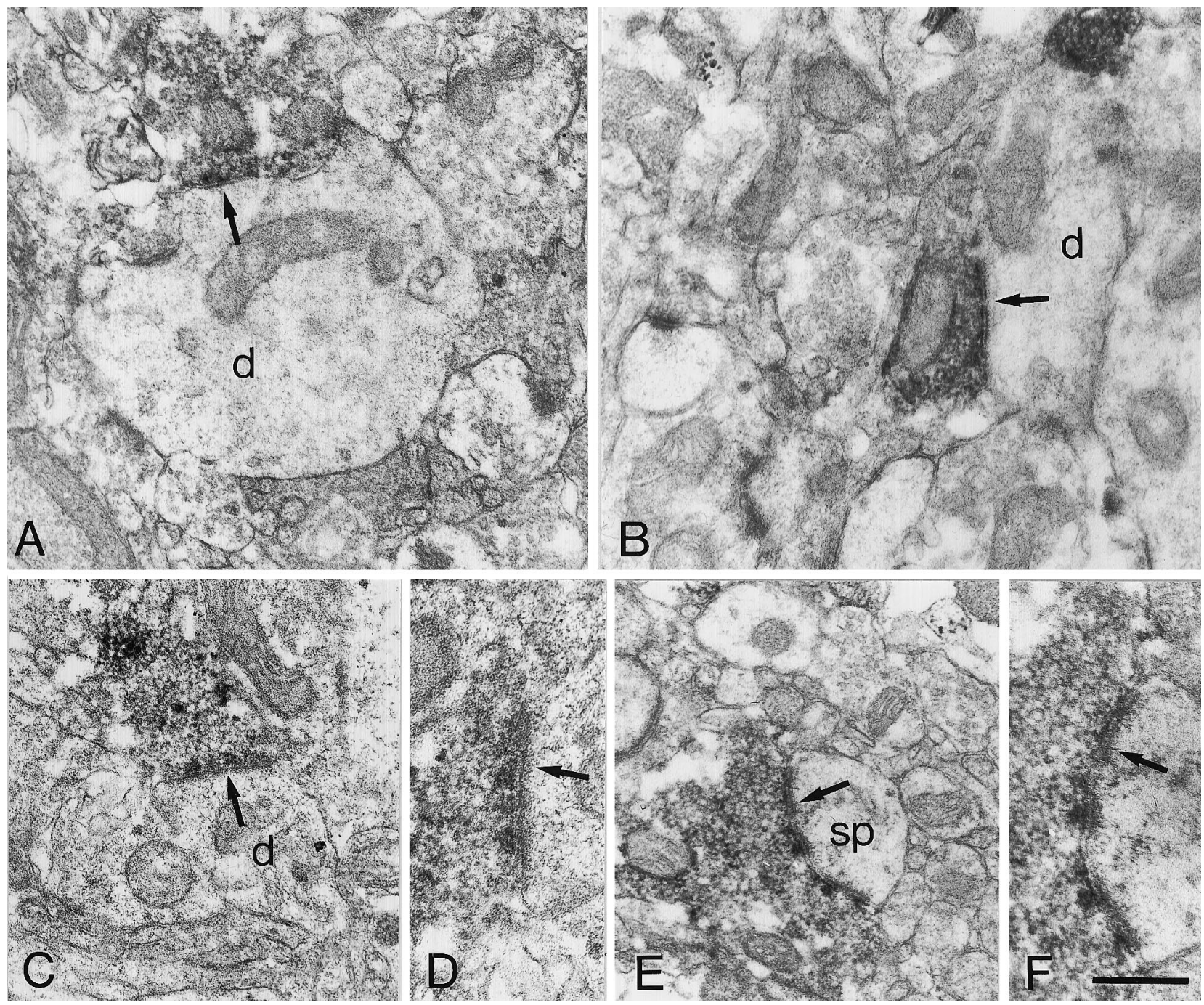

Figure 7. $A, B$, Electron micrographs showing CR-ir terminals forming symmetrical synapses (arrows) with either a large $(A)$ or a small $(B)$ dendrite. $C-F$, Electron micrographs illustrating CR-ir terminals forming asymmetrical synapses (arrows) with a small dendrite $(C)$ or with a dendritic spine $(E)$. $D$ and $F$ are high magnifications of $C$ and $E$, respectively, illustrating the prominence of postsynaptic densities (arrows), which is typical of asymmetrical synapses ( $d$, dendrite; $s p$, spine). All electron micrographs were taken from ultrathin sections stained with uranyl acetate and lead citrate. Scale bars: 0.38 $\mu \mathrm{m}$ for $A-C, E ; 0.23 \mu \mathrm{m}$ for $D, F$.

Colocalization experiments in the human temporal neocortex showed that $30 \%$ of NPNFP-ir neurons and $42 \%$ of CB-ir neurons were double-labeled (Hayes and Lewis, 1992). Furthermore, combination immunocytochemistry for NPNFP and PV in the human temporal neocortex (del Río and DeFelipe, 1994) has shown that between $\sim 54$ and $70 \%$ of NPNFP pyramidal cells in layer III were innervated by PV-ir chandelier cell axons (which innervate axon initial segments). Therefore, the two kinds of CR-ir axons and the PV-ir chandelier cell axons may or may not converge on the same pyramidal cells; it is also possible that different combinations of these axons innervate different populations of pyramidal neurons. Additionally, double-labeling immunofluorescence experiments showed that $\mathrm{CR}$-ir and CB-ir pericellular axons often converged on the same pyramidal cell somata, but the low degree of colocalization of these substances in these axons suggests that they were derived from different types of neurons. The present results further emphasize the complexity of the innervation of pyramidal cells (DeFelipe and Fariñas, 1992).

\section{Relationship among CR-ir multiterminal endings and CR-ir, CB-ir, PV-ir, and GABA-ir nonpyramidal neurons}

Cell bodies and proximal dendrites of CR-ir, CB-ir, and PV-ir nonpyramidal neurons were innervated only occasionally by $\mathrm{CR}$-ir terminals. Because in the primate neocortex many of these neurons are likely also to be GABAergic and to represent a large population of GABAergic neurons (Hendry et al., 1989; van Brederode et al., 1990; Hendry and Carder, 1993; del Río and DeFelipe, 1996a), our results suggest that, in general, GABAergic cell bodies are not postsynaptic targets of CR-ir terminals. This is supported by the findings for pairs of adjacent serial semithin sections processed for CR or GABA postembedding immunocytochemistry, which revealed that the majority of GABA-ir somata was devoid of CR-ir terminals. However, some GABA-ir cell somata that were not CR-ir were innervated by CR-ir multiterminal endings. Furthermore, these cells were surrounded by fewer GABA-ir terminals than CR-ir terminals; therefore, it is possible that some of these pericellular terminals originated from CR-ir/ 
non-GABA-ir cells (see below). Noteworthy in the monkey prefrontal cortex, Gabbott and Bacon (1996), using similar methods to those in the present study, found, however, that CR-ir axons frequently were seen contacting cell bodies and proximal dendrites of CB-ir and PV-ir neurons. Whether the different findings in these studies are related to cytoarchitectonic differences in neuronal circuits or to microanatomical distinctions between human and monkey cerebral cortices remains to be determined.

\section{Close dendro-dendritic appositions}

Dendrites in close apposition with other dendrites and somata were observed in all combination pairs except between CR-ir and CB-ir neurons. Dendro-dendritic appositions appeared to be highly selective because, although the zones of contact were of considerable length, relatively few neurons displayed appositions. Dendro-dendritic synapses, dendro-dendritic or dendro-somatic gap junctions, and other junctional specializations have been described in a number of regions of the CNS (Peters et al., 1991), including the monkey neocortex (Sloper, 1971, 1972; Sloper and Powell, 1978; DeFelipe and Jones, 1985). Furthermore, Gulyás et al. (1996) found in the rat hippocampus that CR-ir neurons often form dendro-dendritic contacts; also in these contacts numerous zonula adherentia were seen at the electron microscope level. Whether in the human neocortex these contacts simply represent adhesive points or have a functional significance remains to be elucidated. However, the selectivity of the dendro-dendritic appositions and the existence of dendro-dendritic synapses and gap junctions in the monkey neocortex incline us to believe that they have an important functional significance (see also Gulyás et al., 1996).

\section{Synaptic connections of CR-ir neurons}

Cell bodies of CR-ir neurons receive very few synapses; thus, their major synaptic input must be on their dendrites. The sources of these synaptic inputs are not known, and, although the cell bodies of the majority of CR-ir neurons are located in layers II and III, it seems clear that those neurons that have long, vertically oriented dendrites (which may transverse several layers) are involved in synaptic circuits different from those having a more local dendritic arborization.

CR-ir axon terminals formed synapses with various postsynaptic elements, including the somata of both pyramidal and nonpyramidal cells, dendritic shafts of large and small caliber, and dendritic spines. A vast majority of axo-somatic synapses were on pyramidal cells and were symmetrical, whereas few axo-somatic synapses were found on nonpyramidal cells being both symmetrical and asymmetrical. As discussed in our previous study (del Río and DeFelipe, 1996a), because large basket cells are not CR-ir, the major source of CR-ir perisomatic terminals on pyramidal cells must be small basket cells. Furthermore, in doublelabeled immunofluorescence material we found pyramidal cell somata innervated by both CB and CR-ir axon terminals, but they were not colocalized, which indicates that different subpopulations of small basket cells converged on the same pyramidal cells.

As reported for the rat visual cortex and hippocampus (Lüth et al., 1993; Gulyás et al., 1996), the types of synapses formed by CR-ir axon terminals in the human temporal neocortex were both symmetrical and asymmetrical. The majority of these synapses $(69 \%)$ was symmetrical, and their source is very likely to be from the population of CR-ir neurons that is also GABA-ir, which represents the major population of CR-ir neurons in the human neocortex (del Río and DeFelipe, 1996a). The sites of termination shown by CR-ir terminals forming asymmetrical synapses were similar to those of the subpopulation of bipolar cells that form this type of synapse in other species (Peters and Kimerer, 1981; Peters and Harriman, 1988) (see also Fairén et al., 1984). In addition, CR-ir neurons with bipolar morphology were very frequent, and colocalization studies in the human temporal neocortex have shown that $\sim 26 \%$ of CR-ir neurons are not GABA-ir (del Río and DeFelipe, 1996a), which is similar to that for axon terminals forming asymmetrical synapses $(31 \%)$. Thus, it is likely that the source of these axon terminals is a subclass of non-GABAergic bipolar neurons. Similarly, some bipolar cells have been shown to be myelinated (Peters and Kimerer, 1981); therefore, it is possible that the CR-ir myelinated axons found in the present study originated from bipolar cells.

The vast majority of postsynaptic dendritic profiles was nonimmunoreactive for $\mathrm{CR}$, which was in line with light microscope observations (see above). Although there were various postsynaptic dendritic profiles, CR-ir axon terminals forming asymmetrical synapses preferentially contacted spines (probably from pyramidal cells), whereas those forming symmetrical synapses were preferentially on dendritic shafts. Some of these dendritic shafts were from pyramidal cells, but the origin of the majority of postsynaptic dendrites could not be identified. We do not know whether the more prominent postsynaptic densities of the synaptic contacts made by CR-ir terminals on labeled postsynaptic elements, as compared with those unlabeled, was attributable simply to an enhancement produced by the deposit of electron-dense peroxidase reaction or to the different natures of these contacts.

In conclusion, these results indicate that CR-ir cells are involved in highly selective and complex synaptic microcircuits in the human temporal neocortex and that different subpopulations of excitatory and inhibitory CR-ir nonpyramidal cells exist, which are specialized for selective innervation of the somatic or dendritic regions of certain pyramidal and nonpyramidal neurons.

\section{REFERENCES}

Andressen C, Blümcke I, Celio MR (1993) Calcium-binding proteins: selective markers of nerve cells. Cell Tissue Res 271:181-208.

Campbell MJ, Morrison JH (1989) Monoclonal antibody to neurofilament protein (SMI-32) labels a subpopulation of pyramidal neurons in the human and monkey neocortex. J Comp Neurol 282:191-205.

Condé F, Lund J, Jacobowitz DM, Baimbridge KG, Lewis DA (1994) Local circuit neurons immunoreactive for calretinin, calbindin D-28k, or parvalbumin in monkey prefrontal cortex: distribution and morphology. J Comp Neurol 341:95-116.

DeFelipe J (1993) Neocortical neuronal diversity: chemical heterogeneity revealed by colocalization studies of classic neurotransmitters, neuropeptides, calcium binding proteins, and cell surface molecules. Cereb Cortex 3:273-289.

DeFelipe J, Fairén A (1993) A simple and reliable method for correlative light and electron microscopic studies. J Histochem Cytochem 41:769-772.

DeFelipe J, Fariñas I (1992) The pyramidal neuron of the cerebral cortex: morphological and chemical characteristics of the synaptic inputs. Prog Neurobiol 39:563-607.

DeFelipe J, Jones EG (1985) Vertical organization of $\gamma$-aminobutyric acid-accumulating intrinsic neuronal systems in monkey cerebral cortex. J Neurosci 5:3246-3260.

DeFelipe J, Hendry SHC, Jones EG (1989) Visualization of chandelier cell axons by parvalbumin immunoreactivity in monkey cerebral cortex. Proc Natl Acad Sci USA 86:2093-2097.

del Río MR, DeFelipe J (1994) A study of SMI 32-stained pyramidal cells, parvalbumin-immunoreactive chandelier cells, and presumptive thalamocortical axons in the human temporal neocortex. J Comp Neurol 342:389-408.

del Río MR, DeFelipe J (1995) A light and electron microscopic study of calbindin D-28k immunoreactive double bouquet cells in the human temporal cortex. Brain Res 690:133-140. 
del Río MR, DeFelipe J (1996a) Colocalization of calbindin D-28k, calretinin, and GABA immunoreactivities in neurons of the human temporal cortex. J Comp Neurol 369:472-482.

del Río MR, DeFelipe J (1996b) Synaptic connections of calretininimmunoreactive neurons in the human temporal neocortex. Soc Neurosci Abstr 22:904.

del Río MR, DeFelipe J (1997) Colocalization of calcium binding proteins in neurons and chandelier cells of the human temporal neocortex. J Chem Neuroanat 12:165-173.

Fairén A, DeFelipe J, Regidor J (1984) Nonpyramidal neurons. General account. In: Cerebral cortex, Vol 1, Cellular components of the cerebral cortex (Peters A, Jones EG, eds), pp 201-253. New York: Plenum.

Feldman ML, Peters A (1978) The forms of non-pyramidal neurons in the visual cortex of the rat. J Comp Neurol 179:761-794.

Ferrer I, Soriano E, Tuñón T, Fonseca M, Guionnet N (1991) Parvalbumin immunoreactive neurons in normal human temporal neocortex and in patients with Alzheimer's disease. J Neurol Sci 106:135-141.

Ferrer I, Tuñón T, Soriano E, del Río A, Iraizoz I, Fonseca M, Guionnet N (1992) Calbindin immunoreactivity in normal human temporal cortex. Brain Res 572:33-41.

Fonseca M, Soriano E (1995) Calretinin-immunoreactive neurons in the normal human temporal cortex and in Alzheimer's disease. Brain Res 691:83-91.

Gabbott PLA, Bacon SJ (1996) Local circuit neurons in the medial prefrontal cortex (areas 24a, b, c, 25, and 32) in the monkey. I. Cell morphology and morphometrics. J Comp Neurol 364:567-608.

Glezer II, Hof PR, Morgane PJ (1992) Calretinin-immunoreactive neurons in the primary visual cortex of dolphin and human brains. Brain Res 595:181-188.

Gulyás AI, Hájos N, Freund TF (1996) Interneurons containing calretinin are specialized to control other interneurons in the rat hippocampus. J Neurosci 16:3397-3411.

Hancock MB (1982) DAB-nickel substrate for the differential immunoperoxidase staining of nerve fibers and fiber terminals. J Histochem Cytochem 30:578.

Hayes TL, Lewis DA (1992) Nonphosphorylated neurofilament protein and calbindin immunoreactivity in layer III pyramidal neurons of human neocortex. Cereb Cortex 2:56-67.

Hendry SHC (1987) Recent advances in understanding the intrinsic circuitry of the cerebral cortex. In: Higher brain functions: recent explorations of the brain's emergent properties (Wise SP, ed), pp 241-283. New York: Wiley.

Hendry SHC, Carder RK (1993) Neurochemical compartmentation of monkey and human visual cortex: similarities and variations in calbindin immunoreactivity across species. Vis Neurosci 10:1109-1120.

Hendry SHC, Jones EG, Emson PC, Lawson DEM, Heizmann CW, Streit P (1989) Two classes of cortical GABA neurons defined by differential calcium-binding protein immunoreactivities. Exp Brain Res 76:467-472.

Hof PR, Cox K, Young WG, Celio MR, Rogers J, Morrison JH (1991) Parvalbumin-immunoreactive neurons in the neocortex are resistant to degeneration in Alzheimer's disease. J Neuropathol Exp Neurol 50:451-462.

Hof PR, Nimchinsky EA, Celio MR, Bouras C, Morrison JH (1993) Calretinin-immunoreactive neocortical interneurons are unaffected in Alzheimer's disease. Neurosci Lett 152:145-149.

Houser CR, Vaughn JE, Hendry SHC, Jones EG, Peters A (1984) GABA neurons in the cerebral cortex. In: Cerebral cortex, Vol 2, Functional properties of cortical cells (Jones EG, Peters A, eds), pp 63-89. New York: Plenum.

Jacobowitz DM, Winsky L (1991) Immunocytochemical localization of calretinin in the forebrain of the rat. J Comp Neurol 304:198-218.

Jones EG (1975) Varieties and distribution of nonpyramidal cells in the somatic sensory cortex of the squirrel monkey. J Comp Neurol 160:205-268.

Jones EG (1993) GABAergic neurons and their role in cortical plasticity in primates. Cereb Cortex 3:361-372.

Kawaguchi Y (1995) Physiological subgroups of nonpyramidal cells with specific morphological characteristics in layer II/III of rat frontal cortex. J Neurosci 15:2638-2655.

Kawaguchi Y, Kubota Y (1993) Correlation of physiological subgroupings of nonpyramidal cells with parvalbumin- and calbindin ${ }_{\mathrm{D} 28 \mathrm{k}^{-}}$ immunoreactive neurons in layer $\mathrm{V}$ of rat frontal cortex. J Neurophysiol 70:387-396.

Lewis DA, Lund JS (1990) Heterogeneity of chandelier neurons in monkey neocortex: corticotropin-releasing factor and parvalbuminimmunoreactive populations. J Comp Neurol 293:599-615.

Lund JS (1990) Excitatory and inhibitory circuiting and laminar mapping strategies in the primary visual cortex of the monkey. In: Signal and sense: local and global order in perceptual maps (Edelman GM, Gall WE, Cowan WM, eds), pp 51-82. New York: Wiley-Liss.

Lüth HJ, Blümcke I, Celio MR (1993) The calcium-binding protein calretinin is localized in a subset of interneurons in the rat cerebral cortex: a light and electron immunohistochemical study. J Hirnforsch 34:93-103.

Marco P, Sola RG, Pulido P, Alijarde MT, Sánchez A, Ramón y Cajal S, DeFelipe J (1996) Inhibitory neurons in the human epileptogenic temporal neocortex: an immunocytochemical study. Brain 119:1327-1348.

Marin-Padilla M (1969) Origin of the pericellular baskets of the pyramidal cells of the human motor cortex: a Golgi study. Brain Res 14:633-646.

Peters A (1987) Synaptic specificity in the cerebral cortex. In: Synaptic function (Edelman GM, Gall WE, Cowan WM, eds), pp 373-397. New York: Wiley.

Peters A, Harriman KM (1988) Enigmatic bipolar cell of rat visual cortex. J Comp Neurol 267:409-432.

Peters A, Kimerer LM (1981) Bipolar neurons in rat visual cortex: a combined Golgi-electron microscope study. J Neurocytol 10:921-946.

Peters A, Palay SL, Webster H deF (1991) The fine structure of the nervous system. Neurons and their supporting cells. New York: Oxford UP.

Résibois A, Rogers JH (1992) Calretinin in rat brain: an immunohistochemical study. Neuroscience 46:101-134.

Ribak CE (1978) Aspinous and sparsely spinous stellate neurons in the visual cortex of rats contain glutamic acid decarboxylase. J Neurocytol 7:461-478.

Sloper JJ (1971) Dendro-dendritic synapses in the primate motor cortex. Brain Res 34:186-192.

Sloper JJ (1972) Gap junctions between dendrites in the primate neocortex. Brain Res 44:641-646.

Sloper JJ, Powell TPS (1978) Gap junctions between dendrites and somata of neurons in the primate sensori-motor cortex. Proc R Soc Lond [Biol] 203:39-47.

Somogyi P (1989) Synaptic organization of GABAergic neurons and $\mathrm{GABA}_{\mathrm{A}}$ receptors in the lateral geniculate nucleus and visual cortex. In: Neural mechanisms of visual perception (Lam DK-T, Gilbert CD, eds), pp 35-62. The Woodlands, TX: Portfolio.

van Brederode JFM, Mulligan KA, Hendrickson AE (1990) Calciumbinding proteins as markers for subpopulations of GABAergic neurons in monkey striate cortex. J Comp Neurol 298:1-22.

White EL (1989) Cortical circuits: synaptic organization of the cerebral cortex. Structure, function, and theory. Boston: Birkhäuser.

Williams SM, Goldman-Rakic PS, Leranth C (1992) The synaptology of parvalbumin-immunoreactive neurons in the primate prefrontal cortex. J Comp Neurol 320:353-369. 